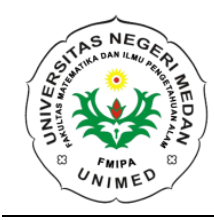

\author{
JURNAL EINSTEIN \\ Jurnal Hasil Penelitian Bindang Fisika \\ Available online http://jurnal.unimed.ac.id/2012/index.php/einsten \\ e-issn: $2407-747 x$, p-issn $2338-1981$
}

\title{
ANALISIS AIR SUMUR BOR DESA PEKAN BANDAR KHALIFAH KABUPATEN SERDANG BEDAGAI BERDASARKAN KUALITAS FISIKA DAN KIMIA
}

\author{
Donita Manurung dan Eva Marlina Ginting \\ Jurusan Fisika, Fakultas Matematika dan Ilmu Pengetahuan Alam, Universitas Negeri Medan, \\ Indonesia \\ donitha26@gmail.com \\ Diterima April 2018; Disetujui Mei 2018; Dipublikasikan Juni 2018
}

\begin{abstract}
ABSTRAK
Air bersih merupakan air yang dipergunakan untuk keperluan sehari-hari dan kualitasnya memenuhi persyaratan kesehatan air bersih sesuai dengan peraturan perundang-undangan yang berlaku dan dapat diminum apabila dimasak. Maka dalam hal ini, penelitian bertujuan untuk mengetahui kualitas air sumur bor yang berada pada Desa Pekan Bandar Khalifah Kabupaten Serdang Bedagai berdasarkan parameter fisik dan kimia dan untuk mengetahui tingkat pencemaran air sumur bor tersebut. Metode analisis air dilakukan dengan membandingkan hasil observasi terhadap parameter baku mutu air minum menurut PERMENKES No.492 Tahun 2010 mengenai Persyaratan Kualitas Air Minum. Pengambilan sampel dilakukan dengan mengambil air sumur bor dari sepuluh sumur bor dengan mengukur Kekeruhan, Zat Padat Terlarut, Tingkat Keasaman ( $\mathrm{pH})$ dan kandungan unsur Besi ( $\mathrm{Fe})$, Mangan ( $\mathrm{Mn})$, Sulfat $\left(\mathrm{SO}_{4}\right)$ dan Nitrit $\left(\mathrm{NO}_{2}\right)$ yang terkandung dalam air sumur bor tersebut. Hasil menunjukkan untuk jumlah parameter yang melampaui baku mutu air minum yakni parameter besi (Fe), $\mathrm{pH}$ dan dapat disimpulkan bahwa mutu air di kawasan Desa Pekan Bandar Khalifah tergolong dalam air dengan tingkat tercemar ringan yang memerlukan pengolahan terlebih dahulu sebelum dikonsumsi dengan cemar maksimum sebesar 2,21 dan cemar minimum sebesar 1,03.
\end{abstract}

Kata Kunci : Air Sumur Bor, Kualitas Air, Parameter Fisika, Parameter Kimia.

\section{PENDAHULUAN}

Air bersih merupakan air yang dipergunakan untuk keperluan sehari-hari dan kualitasnya memenuhi persyaratan kesehatan air bersih sesuai dengan peraturan perundangundangan yang berlaku dan dapat diminum apabila dimasak (Parera,2013). Untuk mencapai standar kualitas yang baik, air baku harus diproses dan diolah sesuai karakteristik air tersebut dan kebutuhan air yang dikonsumsi setidaknya memenuhi syarat secara umum yakni tidak berasa, tidak berwarna, tidak berbau dan tidak mengandung logam.

Menurut Dirjen PPM PLP Depkes Republik Indonesia yang disebut sebagai air bersih adalah air yang memenuhi syarat kesehatan dan harus dimasak terlebih dahulu sebelum diminum, Sedangkan yang disebut sebagai air minum adalah air yang melalui proses pengolahan atau tanpa proses pengolahan yang memenuhi syarat kesehatan dan dapat langsung diminum. 
Namun sering dijumpai bahwa banyak penduduk yang terpaksa memanfaatkan air yang kurang baik kualitasnya. Kualitas air yang kurang baik pada jangka pendek dapat mengakibatkan muntaber, diare, kolera, tipus, atau disentri. Bila air tanah dan air permukaan tercemari oleh kotoran, secara otomatis kuman-kuman tersebar ke sumber air yang dipakai untuk keperluan rumah tangga. Sedangkan dalam jangka panjang, air yang berkualitas buruk dapat mengakibatkan penyakit keropos tulang, korosi gigi, anemia dan kerusakan ginjal. Hal ini terjadi karena terdapatnya logam-logam yang berat yang banyak bersifat toksik (racun) dan terdapat pengendapan pada ginjal (Suryana,2013).

Pemanfaatan air sumur sebagai sumber pasokan air bersih untuk berbagai keperluan di daerah lepasan air tanah (discharge area) memperlihatkan kecenderungan yang terus meningkat, sementara itu pemanfaatan lahan di daerah resapan air tanah (recharge area) juga mengalami perubahan seiring dengan kemajuan pembangunan. Beberapa akibat yang ditimbulkan adanya pemompaan yang berlebihan antara lain terjadinya penurunan muka air tanah dan berkurangnya cadangan air tanah (Rolia,2011).

Bandar Khalifah merupakan salah satu kecamatan di Kabupaten Serdang Bedagai. Secara geografis kecamatan Bandar Khalipah adalah wilayah pantai dan dataran rendah yang terdiri dari 5 desa yaitu Desa Bandar Tengah, Desa Juhar, Desa Gelam Sei Serimah, Desa Pekan Bandar Khalifah dan Desa Kayu Besar. Adapun luas kecamatan Bandar Khalifah adalah $11.600 \mathrm{Ha}$ atau $116 \mathrm{~km}^{2}$ yang berada di ketinggian 0-10 meter dari permukaan laut. Desa Pekan Bandar Khalifah secara geografis terletak pada posisi $3^{\circ}$ 26' 55.94" Lintang Utara dan 99 17'02.45” Bujur Timur. Desa Pekan Bandar Khalifah memiliki luas wilayah sebesar $2010 \mathrm{Ha}$ dan 7 Dusun dengan jumlah penduduk sebanyak 6363 jiwa.

Air sumur bor merupakan salah satu sumber air yang digunakan oleh masyarakat Desa Bandar Khalifah untuk kehidupan sehari-hari. Pada desa tersebut terdapat beberapa sumur bor yang disalurkan ke sebagian rumah. Sumur bor tersebut memiliki jarak kurang lebih 3,5 km dari garis pantai. Menurut warga sekitar, air yang disalurkan dari sumur bor tersebut tidak berfungsi dengan efisien karena air yang dihasilkan berbau belerang atau telur, bersuhu panas, terasa asin, tidak nyaman ketika digunakan untuk membersihkan badan saat mandi sebab buih sabun yang terkena air tersebut menjadi banyak dan tubuh terasa licin dan pada beberapa air sumur bor ada yang tidak dikonsumsi.

\section{METODE PENLITIAN \\ Pengukuran Parameter Fisika}

Analisis Zat Padat Terlarut dilakukan dengan menggunakan Alat ukut TDS meter, langkah kerjanya adalah, pertama sampel air dimasukkan ke dalam gelas ukur $100 \mathrm{ml}$, dimana gelas ukur tersebut dibersihkan terlebih dahulu dengan menggunakan aquadest kemudian dikeringkan dengan menggunakan tissu. Selanjutnya Elektroda TDS meter dicelupkan ke dalam sampel air dan ditekan tombol ON untuk menghidupkan alat ukur TDS meter sampai pada layar muncul nilai. Nilai yang keluar pada alat ukur kemudian dicatat. Setelah itu ditekan tombol OFF untuk mematikan alat ukur.

Analisis kekeruhan di dalam air dapat dilakukan dengan alat ukur turbidimeter, cara analisis kekeruhan pada air yaitu dengan menghidupkan terlebih dahulu alat turbidimeter dengan menekan tombol power. Selanjutnya sampel dimasukkan ke dalam kuvet sebanyak 15 ml, dimana kuvet tersebut terlebih dahulu dibersihkan dengan aquadest dan dikeringkan dengan menggunakan tissu. Kemudian dimasukan kuvet ke dalam Turbidimeter, lalu ditekan Read hingga pada alat menunjukan nilai kekeruhan pada air. Nilai tersebut dicatat dan selanjutnya untuk mematikan alat ukur turbidimeter dengan menekan tombol power.

\section{Pengukuran Parameter Kimia}

$\mathrm{pH}$ di dalam air dianalisis dengan menggunakan alat ukur $\mathrm{pH}$ meter. Cara pengujiannya adalah sampel air dimasukkan ke dalam gelas ukur sebanyak $100 \mathrm{ml}$, dimana gelas ukur harus dibersihkan terlebih dahulu dengan menggunakan aquades kemudian dikeringkan dengan menggunakan tissu. Selanjutnya elektroda pada alat ukur $\mathrm{pH}$ meter tersebut dicelupkan ke dalam sampel dan ditekan tombol ON sampai muncul nilai pada layar alat ukur. Nilai itulah yang kemudian dicatat. Selanjutnya ditekan 
tombol OFF untuk mematikan alat ukur $\mathrm{pH}$ meter.

Pengujian unsur-unsur kimia di dalam air sumur bor dilakukan di BARISTAND (Balai Riset dan Standarisasi). Larutan standar dibuat dengan mengambil $5 \mathrm{~mL}$ larutan standar yang terkontaminasi $\mathrm{Fe}, \mathrm{Mn}, \mathrm{NO}_{2}$ dan $\mathrm{SO}_{4} 100 \mathrm{mg} / \mathrm{L}$. Kemudian dimasukkan ke dalam labu ukur yang berisi air distilasi dengan volume air $10 \mathrm{~mL}$. Konsentrasi ini kemudian diencerkan kembali menjadi konsentrasi $0,1 \mathrm{mg} / \mathrm{L} ; 0,2 \mathrm{mg} / \mathrm{L} ; 0,3 \mathrm{mg} / \mathrm{L}$; $0,4 \mathrm{mg} / \mathrm{L} ; 0,5 \mathrm{mg} / \mathrm{L}$ dengan memakai mikropipet volume $5 \mathrm{~mL}$.

Pengoperasian ASS (Atomic Absorption Spectroscopy) dimulai dengan memasang terlebih dahulu lampu katoda yang sesuai dengan logam yang akan dianalisis. Kemudian AAS dihubungkan dengan sumber arus, dan lampu dipanaskan sampai 10 menit. Api pembakar (flame) dinyalakan dengan bantuan asitelin. Intensitas api diatur hingga memberikan warna biru. Setelah itu, panjang gelombang diatur untuk memperoleh serapan maksimum setiap unsur. Posisi lampu juga diatur untuk memperoleh serapan maksimum. Aspirasi larutan blangko ke dalam nyala udara asetilen, penunjukan hasil bacaan pengukuran harus nol dengan menekan tombol nol. Secara berturut-turut konsentrasi larutan baku diaspirasi ke dalam AAS, dan dilanjutkan dengan larutan sampel. Hasil pengukuran serapan atom disampaikan dengan sinyal ke komputer untuk mendapat konsentrasi unsur pada air sumur bor tersebut.

\section{Analisa Kelayakan Air Sumur Bor}

Untuk menetapkan kelayakan air sumur sebagai bor, hasil analisis di laboratorium akan ditetapkan berdasarkan Peraturan Menteri Kesehatan No. 492 Tahun 2010 mengenai Persyaratan Kualitas Air Minum (Menteri Kesehatan Republik Indonesia,2010). Ketetapan tersebut mengacu pada kadar maksimum parameter kualitas air yang diperbolehkan. Mutu kualitas air dan tingkat pencemarannya ditentukan dengan menggunakan Metode Indeks Pencemaran, yang mengacu pada Keputusan Menteri Negara Lingkungan Hidup No.115 Tahun 2003 tentang Status Mutu Air. Tata cara penentuan mutu air dengan menggunakan Metode Indeks Pencemaran, yakni :
Jika L $\mathrm{L}_{\mathrm{ij}}$ menyatakan konsentrasi parameter kualitas air yang dicantumkan dalam Baku Mutu suatu Peruntukan Air (j), dan $\mathrm{C}_{i}$ menyatakan konsentrasi parameter kualitas air (i) yang diperoleh dari hasil analisis air pada suatu lokasi pengambilan sampel dari sumur bor, maka $P_{i j}$ adalah Indeks Pencemaran bagi peruntukan (j) yang merupakan fungsi dari $\mathrm{C}_{\mathrm{i}} / \mathrm{L}_{\mathrm{ij}}$.

Harga $\mathrm{P}_{\mathrm{ij}}$ ini dapat ditentukan dengan cara :

1. Pilih parameter-parameter yang jika nilai parameter rendah maka kualitas air akan membaik.

2. Pilih konsentrasi parameter baku mutu yang tidak memiliki rentang.

3. Hitung harga $\mathrm{C}_{\mathrm{i}} / \mathrm{L}_{\mathrm{ij}}$ untuk tiap parameter pada setiap lokasi pengambilan sampel.

4. a) Jika nilai konsentrasi parameter yang menurun menyatakan tingkat pencemaran meningkat, Tentukan nilai teoritik atau nilai maksimum $\mathrm{C}_{\mathrm{im}}$.

Dalam kasus ini nilai $\mathrm{C}_{\mathrm{i}} / \mathrm{L}_{\mathrm{ij}}$ hasil pengukuran digantikan oleh nilai $\mathrm{C}_{\mathrm{i}} / \mathrm{L}_{\mathrm{ij}}$ hasil perhitungan, yaitu :

$\left(C_{i} / L_{i j}\right)$ baru $=\frac{(\text { Cim }-C i(\text { hasil pengukuran }))}{C i m-L i j}$

b) Jika nilai baku $\mathrm{L}_{\mathrm{ij}}$ memiliki rentang Untuk $\mathrm{C}_{\mathrm{ij}} \leq \mathrm{L}_{\mathrm{ij}}$ rata-rata

$\left(C_{i} / L_{i j}\right)$ baru $=\frac{[C i-(\text { Lij }) \text { rata }- \text { rata }]}{\{(\text { Lij }) \text { min imum }-(\text { Lij }) \text { rata }- \text { rata }}$

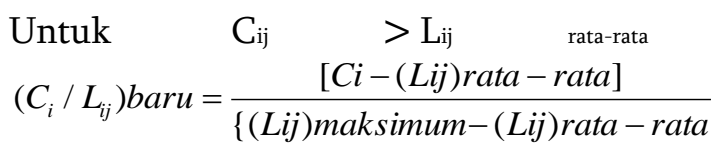

5. Keraguan timbul jika dua nilai $\left(\mathrm{C}_{\mathrm{i}} / \mathrm{Lij}\right)$ berdekatan dengan nilai acuan 1,0, misal $\mathrm{C}_{1} / \mathrm{L}_{1 j}=0,9$ dan $\mathrm{C}_{2} / \mathrm{L}_{2 j}=1,1$ atau perbedaan yang sangat besar, misal $\mathrm{C}_{3} / \mathrm{L}_{3 j}$ $=5,0$ dan $\mathrm{C}_{4} / \mathrm{L}_{4 j}=10,0$. Dalam contoh ini tingkat kerusakan badan air sulit ditentukan. Cara untuk mengatasi kesulitan ini adalah :

a) Pengunaan nilai $\left(\mathrm{C}_{\mathrm{i}} / \mathrm{L}_{\mathrm{ij}}\right)$ hasil pengukuran kalau nilai ini lebih kecil dari 1,0

b) Penggunaan nilai $\left(\mathrm{C}_{\mathrm{i}} / \mathrm{L}_{\mathrm{ij}}\right)$ baru jika nilai $\left(\mathrm{C}_{\mathrm{i}} / \mathrm{L}_{\mathrm{ij}}\right)$ hasil pengukuran lebih besar dari 1,0

$\left(\mathrm{C}_{\mathrm{i}} / \mathrm{L}_{\mathrm{ij}}\right)$ baru $=1,0+\mathrm{P} \cdot \log \left(\mathrm{C}_{\mathrm{i}} / \mathrm{L}_{\mathrm{ij}}\right)$ hasil pengukuran (2.4)

$\mathrm{P}$ adalah konstanta dan nilainya ditentukan dengan bebas dan disesuaikan 
dengan hasil pengamatan lingkungan dan atau persyaratan yang dikehendaki untuk suatu peruntukan (biasanya digunakan nilai 5).

6. Tentukan nilai rata-rata dan nilai maksimum dari keseluruhan $\mathrm{C}_{\mathrm{i}} / \mathrm{L}_{\mathrm{ij}}$ $\left(\left(\mathrm{C}_{\mathrm{i}} / \mathrm{L}_{\mathrm{ij}}\right) \mathrm{R} \operatorname{dan}\left(\mathrm{C}_{\mathrm{i}} / \mathrm{L}_{\mathrm{ij}}\right) \mathrm{M}\right)$.

7. Tentukan nilai $\mathrm{L}_{\mathrm{ij}}$

$P_{i j}=\sqrt{\frac{\left(\frac{C i}{L i j}\right)^{2} M+\left(\frac{C i}{L i j}\right)^{2} R}{2}}$

Setelah mendapatkan nilai $\mathrm{C}_{\mathrm{i}} / \mathrm{L}_{\mathrm{ij}}$ baru dari keseluruhan parameter yang dianalisis ditentukan nilai $\mathrm{C}_{\mathrm{i}} / \mathrm{L}_{\mathrm{ijmaksimum}}$ dan $\mathrm{C}_{\mathrm{i} / \mathrm{Lijrata-rata}}$ kemudian ditentukan Indeks pencemaran dengan menggunakan persamaan (2.6).

$P_{i j}=\sqrt{\frac{\left(\frac{C i}{L i j}\right)^{2} M+\left(\frac{C i}{L i j}\right)^{2} R}{2}}$

Mutu kualitas air dikategorikan seperti yang tercantum dalam tabel (1.1) berdasarkan Keputusan Menteri Lingkungan hidup No.115 Tahun 2003.

Tabel 1.1. Kategori mutu kualitas Air

\begin{tabular}{|c|c|}
\hline $\begin{array}{c}\text { Indeks } \\
\text { Kualitas Air }\end{array}$ & Keterangan \\
\hline $0 \leq \mathrm{P}_{\mathrm{ij}} \leq 1,0$ & $\begin{array}{c}\text { Memenuhi Baku Mutu } \\
\text { (kondisi Baik) }\end{array}$ \\
\hline $1,0<\mathrm{P}_{\mathrm{ij}} \leq 5,0$ & Cemar Ringan \\
\hline $5,0<\mathrm{P}_{\mathrm{ij}} \leq 10$ & Cemar Sedang \\
\hline $\mathrm{P}_{\mathrm{ij}}>10$ & Cemar Berat \\
\hline
\end{tabular}

(Kementerian Negara Lingkungan Hidup,2003)

\section{HASIL DAN PEMBAHASAN \\ 3.1 HASIL PENELITIAN}

\subsubsection{Kualitas Fisika Air Sumur Bor}

Tabel 3.1. Kualitas fisika air sumur bor

\begin{tabular}{|c|c|c|c|c|c|}
\hline \multirow[b]{2}{*}{$\begin{array}{c}\text { Ko } \\
\text { de } \\
\text { Sa } \\
\text { m } \\
\text { pel }\end{array}$} & \multirow[b]{2}{*}{$\begin{array}{c}\text { Ke } \\
\text { da } \\
\text { la } \\
\text { m } \\
\text { an } \\
(\mathbf{m} \\
)^{*}\end{array}$} & \multicolumn{4}{|c|}{ Parameter Fisika } \\
\hline & & $\begin{array}{c}\text { Keke } \\
\text { ruha } \\
\text { n } \\
\text { (NT } \\
\text { U) }\end{array}$ & $\begin{array}{c}\text { Ketera } \\
\text { ngan }\end{array}$ & $\begin{array}{c}\text { Zat } \\
\text { Padat } \\
\text { Terlar } \\
\text { ut } \\
(\mathrm{mg} / \mathrm{l})\end{array}$ & $\begin{array}{c}\text { Ketera } \\
\text { ngan }\end{array}$ \\
\hline IA & $\begin{array}{c}24 \\
6\end{array}$ & 2,34 & $\begin{array}{l}\text { Tidak } \\
\text { melewa } \\
\text { ti batas } \\
\text { baku }\end{array}$ & 396 & $\begin{array}{l}\text { Tidak } \\
\text { melewa } \\
\text { ti batas } \\
\text { baku }\end{array}$ \\
\hline
\end{tabular}

\begin{tabular}{|c|c|c|c|c|c|}
\hline & & & $\begin{array}{l}\text { mutu } \\
\text { air } \\
\text { minum }\end{array}$ & & $\begin{array}{c}\text { mutu } \\
\text { air } \\
\text { minum }\end{array}$ \\
\hline IB & $\begin{array}{c}15 \\
6\end{array}$ & 0,66 & $\begin{array}{c}\text { Tidak } \\
\text { melewa } \\
\text { ti batas } \\
\text { baku } \\
\text { mutu } \\
\text { air } \\
\text { minum }\end{array}$ & 103 & $\begin{array}{c}\text { Tidak } \\
\text { melewa } \\
\text { ti batas } \\
\text { baku } \\
\text { mutu } \\
\text { air } \\
\text { minum }\end{array}$ \\
\hline $\begin{array}{l}\text { II } \\
\text { A }\end{array}$ & $\begin{array}{c}14 \\
4\end{array}$ & 0,66 & $\begin{array}{c}\text { Tidak } \\
\text { melewa } \\
\text { ti batas } \\
\text { baku } \\
\text { mutu } \\
\text { air } \\
\text { minum }\end{array}$ & 103 & $\begin{array}{c}\text { Tidak } \\
\text { melewa } \\
\text { ti batas } \\
\text { baku } \\
\text { mutu } \\
\text { air } \\
\text { minum }\end{array}$ \\
\hline $\begin{array}{l}\text { II } \\
\text { B }\end{array}$ & $\begin{array}{c}15 \\
6\end{array}$ & 0,55 & $\begin{array}{c}\text { Tidak } \\
\text { melewa } \\
\text { ti batas } \\
\text { baku } \\
\text { mutu } \\
\text { air } \\
\text { minum }\end{array}$ & 51 & $\begin{array}{c}\text { Tidak } \\
\text { melewa } \\
\text { ti batas } \\
\text { baku } \\
\text { mutu } \\
\text { air } \\
\text { minum }\end{array}$ \\
\hline $\begin{array}{c}\text { III } \\
\text { A }\end{array}$ & $\begin{array}{c}15 \\
0\end{array}$ & 0,66 & $\begin{array}{c}\text { Tidak } \\
\text { melewa } \\
\text { ti batas } \\
\text { baku } \\
\text { mutu } \\
\text { air } \\
\text { minum }\end{array}$ & 103 & $\begin{array}{c}\text { Tidak } \\
\text { melewa } \\
\text { ti batas } \\
\text { baku } \\
\text { mutu } \\
\text { air } \\
\text { minum }\end{array}$ \\
\hline $\begin{array}{c}\text { III } \\
\text { B }\end{array}$ & $\begin{array}{c}13 \\
2\end{array}$ & 0,74 & $\begin{array}{c}\text { Tidak } \\
\text { melewa } \\
\text { ti batas } \\
\text { baku } \\
\text { mutu } \\
\text { air } \\
\text { minum }\end{array}$ & 160 & $\begin{array}{c}\text { Tidak } \\
\text { melewa } \\
\text { ti batas } \\
\text { baku } \\
\text { mutu } \\
\text { air } \\
\text { minum }\end{array}$ \\
\hline $\begin{array}{c}\text { IV } \\
\text { A }\end{array}$ & $\begin{array}{c}12 \\
6\end{array}$ & 3,00 & $\begin{array}{c}\text { Tidak } \\
\text { melewa } \\
\text { ti batas } \\
\text { baku } \\
\text { mutu } \\
\text { air } \\
\text { minum }\end{array}$ & 512 & $\begin{array}{c}\text { Melewa } \\
\text { ti batas } \\
\text { baku } \\
\text { mutu } \\
\text { air } \\
\text { minum }\end{array}$ \\
\hline $\begin{array}{c}\text { IV } \\
\text { B }\end{array}$ & $\begin{array}{c}12 \\
6\end{array}$ & 0,83 & $\begin{array}{c}\text { Tidak } \\
\text { melewa } \\
\text { ti batas } \\
\text { baku } \\
\text { mutu }\end{array}$ & 197 & $\begin{array}{c}\text { Tidak } \\
\text { melewa } \\
\text { ti batas } \\
\text { baku } \\
\text { mutu }\end{array}$ \\
\hline
\end{tabular}




\begin{tabular}{|c|c|c|c|c|c|}
\hline & & & $\begin{array}{c}\text { air } \\
\text { minum }\end{array}$ & & $\begin{array}{c}\text { air } \\
\text { minum }\end{array}$ \\
\hline $\begin{array}{l}\text { VI } \\
\mathrm{A}\end{array}$ & $\begin{array}{c}13 \\
2\end{array}$ & 1,11 & $\begin{array}{c}\text { Tidak } \\
\text { melewa } \\
\text { ti batas } \\
\text { baku } \\
\text { mutu } \\
\text { air } \\
\text { minum }\end{array}$ & 282 & $\begin{array}{c}\text { Tidak } \\
\text { melewa } \\
\text { ti batas } \\
\text { baku } \\
\text { mutu } \\
\text { air } \\
\text { minum }\end{array}$ \\
\hline $\begin{array}{l}\text { VI } \\
\text { B }\end{array}$ & $\begin{array}{c}15 \\
0\end{array}$ & 0,90 & $\begin{array}{c}\text { Tidak } \\
\text { melewa } \\
\text { ti batas } \\
\text { baku } \\
\text { mutu } \\
\text { air } \\
\text { minum }\end{array}$ & 250 & $\begin{array}{c}\text { Tidak } \\
\text { melewa } \\
\text { ti batas } \\
\text { baku } \\
\text { mutu } \\
\text { air } \\
\text { minum }\end{array}$ \\
\hline
\end{tabular}

*melalui informasi masyarakat Desa Pekan Bandar Khalifah

\subsubsection{Kualitas Kimia Air Sumur Bor}

Tabel 3.2. Kualitas kimia air sumur bor

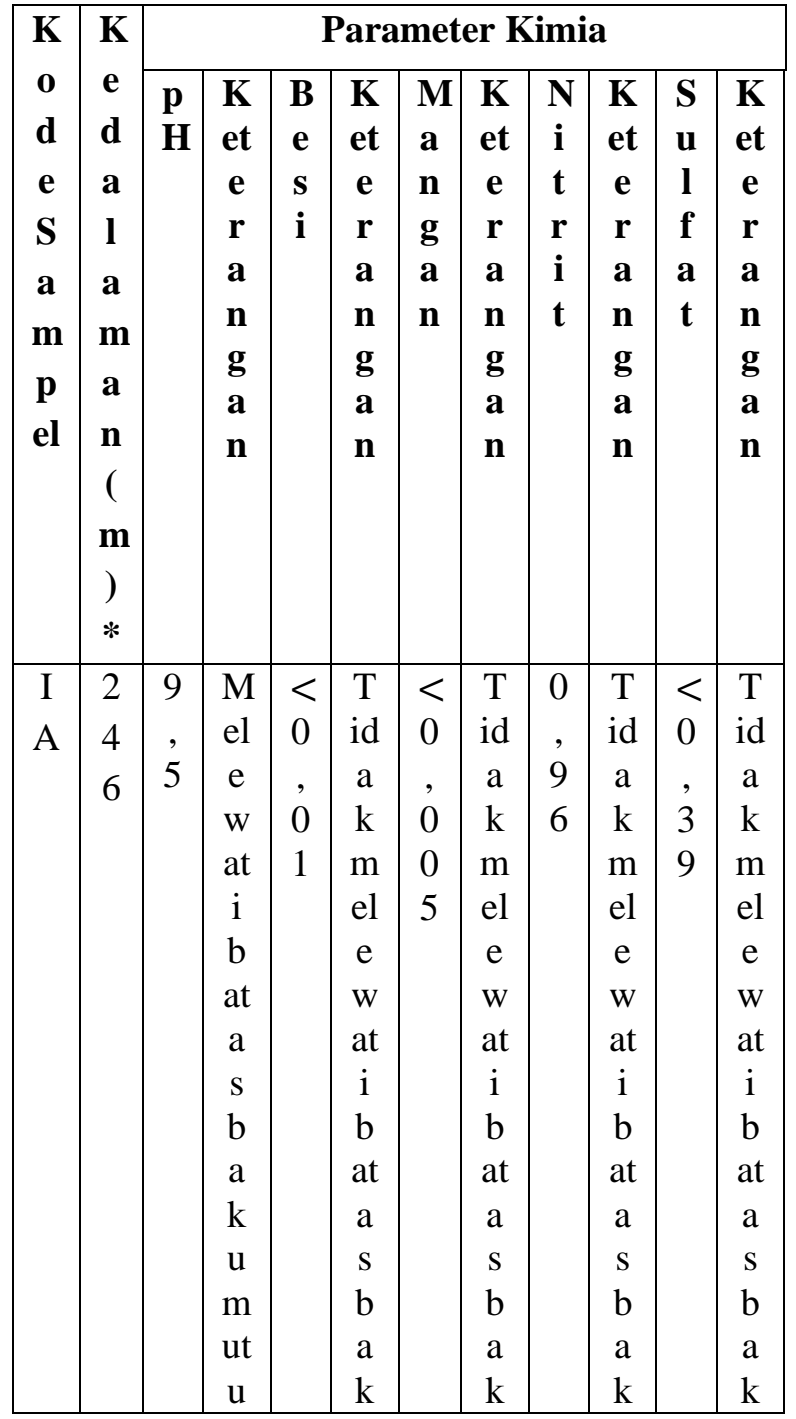

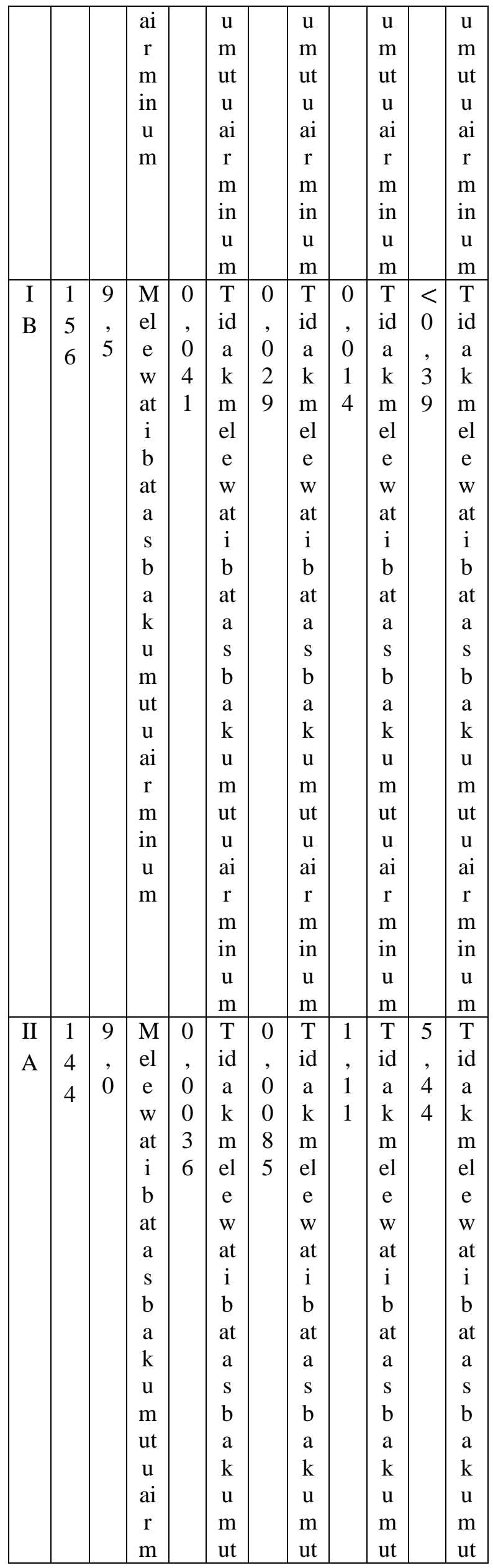




\begin{tabular}{|c|c|c|c|c|c|c|c|c|c|c|c|}
\hline & & & $\begin{array}{l}\text { in } \\
\mathrm{u} \\
\mathrm{m}\end{array}$ & & $\begin{array}{c}\mathrm{u} \\
\text { ai } \\
\mathrm{r} \\
\mathrm{m} \\
\text { in } \\
\mathrm{u} \\
\mathrm{m}\end{array}$ & & $\begin{array}{c}\mathrm{u} \\
\mathrm{ai} \\
\mathrm{r} \\
\mathrm{m} \\
\mathrm{in} \\
\mathrm{u} \\
\mathrm{m}\end{array}$ & & $\begin{array}{c}\mathrm{u} \\
\mathrm{ai} \\
\mathrm{r} \\
\mathrm{m} \\
\mathrm{in} \\
\mathrm{u} \\
\mathrm{m}\end{array}$ & & $\begin{array}{c}\mathrm{u} \\
\mathrm{ai} \\
\mathrm{r} \\
\mathrm{m} \\
\text { in } \\
\mathrm{u} \\
\mathrm{m}\end{array}$ \\
\hline $\begin{array}{l}\text { II } \\
\text { B }\end{array}$ & $\begin{array}{l}1 \\
5\end{array}$ & $\begin{array}{l}9 \\
3\end{array}$ & $\begin{array}{c}\text { M } \\
\text { el } \\
\text { e } \\
\mathrm{w} \\
\text { at } \\
\mathrm{i} \\
\mathrm{b} \\
\mathrm{at} \\
\mathrm{a} \\
\mathrm{s} \\
\mathrm{b} \\
\mathrm{a} \\
\mathrm{k} \\
\mathrm{u} \\
\mathrm{m} \\
\mathrm{ut} \\
\mathrm{u} \\
\mathrm{ai} \\
\mathrm{r} \\
\mathrm{m} \\
\text { in } \\
\mathrm{u} \\
\mathrm{m}\end{array}$ & $\begin{array}{l}< \\
0 \\
, \\
0 \\
1\end{array}$ & $\begin{array}{c}\mathrm{T} \\
\mathrm{id} \\
\mathrm{a} \\
\mathrm{k} \\
\mathrm{m} \\
\mathrm{el} \\
\mathrm{e} \\
\mathrm{w} \\
\mathrm{at} \\
\mathrm{i} \\
\mathrm{b} \\
\mathrm{at} \\
\mathrm{a} \\
\mathrm{s} \\
\mathrm{b} \\
\mathrm{a} \\
\mathrm{k} \\
\mathrm{u} \\
\mathrm{m} \\
\mathrm{ut} \\
\mathrm{u} \\
\mathrm{ai} \\
\mathrm{r} \\
\mathrm{m} \\
\text { in } \\
\mathrm{u} \\
\mathrm{m}\end{array}$ & $\begin{array}{l}3 \\
0 \\
0 \\
7 \\
6\end{array}$ & $\begin{array}{c}\mathrm{T} \\
\mathrm{id} \\
\mathrm{a} \\
\mathrm{k} \\
\mathrm{m} \\
\mathrm{el} \\
\mathrm{e} \\
\mathrm{w} \\
\mathrm{at} \\
\mathrm{i} \\
\mathrm{b} \\
\mathrm{at} \\
\mathrm{a} \\
\mathrm{s} \\
\mathrm{b} \\
\mathrm{a} \\
\mathrm{k} \\
\mathrm{u} \\
\mathrm{m} \\
\mathrm{ut} \\
\mathrm{u} \\
\mathrm{ai} \\
\mathrm{r} \\
\mathrm{m} \\
\text { in } \\
\mathrm{u} \\
\mathrm{m}\end{array}$ & , & $\begin{array}{c}\mathrm{T} \\
\mathrm{id} \\
\mathrm{a} \\
\mathrm{k} \\
\mathrm{m} \\
\mathrm{el} \\
\mathrm{e} \\
\mathrm{w} \\
\mathrm{at} \\
\mathrm{i} \\
\mathrm{b} \\
\mathrm{at} \\
\mathrm{a} \\
\mathrm{s} \\
\mathrm{b} \\
\mathrm{a} \\
\mathrm{k} \\
\mathrm{u} \\
\mathrm{m} \\
\mathrm{ut} \\
\mathrm{u} \\
\mathrm{ai} \\
\mathrm{r} \\
\mathrm{m} \\
\mathrm{in} \\
\mathrm{u} \\
\mathrm{m}\end{array}$ & 3 & $\begin{array}{c}\mathrm{T} \\
\mathrm{id} \\
\mathrm{a} \\
\mathrm{k} \\
\mathrm{m} \\
\mathrm{el} \\
\mathrm{e} \\
\mathrm{w} \\
\mathrm{at} \\
\mathrm{i} \\
\mathrm{b} \\
\mathrm{at} \\
\mathrm{a} \\
\mathrm{s} \\
\mathrm{b} \\
\mathrm{a} \\
\mathrm{k} \\
\mathrm{u} \\
\mathrm{m} \\
\mathrm{ut} \\
\mathrm{u} \\
\mathrm{ai} \\
\mathrm{r} \\
\mathrm{m} \\
\text { in } \\
\mathrm{u} \\
\mathrm{m}\end{array}$ \\
\hline $\begin{array}{c}\text { II } \\
\text { I } \\
\text { A }\end{array}$ & $\begin{array}{l}1 \\
5\end{array}$ & $\begin{array}{l}9 \\
2\end{array}$ & $\begin{array}{c}\text { M } \\
\text { el } \\
\text { e } \\
\mathrm{w} \\
\text { at } \\
\mathrm{i} \\
\mathrm{b} \\
\text { at } \\
\mathrm{a} \\
\mathrm{s} \\
\mathrm{b} \\
\mathrm{a} \\
\mathrm{k} \\
\mathrm{u} \\
\mathrm{m} \\
\mathrm{ut} \\
\mathrm{u} \\
\mathrm{ai} \\
\mathrm{r} \\
\mathrm{m} \\
\text { in } \\
\mathrm{u} \\
\mathrm{m}\end{array}$ & $\begin{array}{l}0 \\
, \\
0 \\
3 \\
6\end{array}$ & $\begin{array}{c}\text { T } \\
\text { id } \\
\text { a } \\
k \\
\text { m } \\
\text { el } \\
\text { e } \\
\text { w } \\
\text { at } \\
\text { i } \\
\text { b } \\
\text { at } \\
\text { a } \\
\text { s } \\
\text { b } \\
\text { a } \\
k \\
\text { u } \\
\text { m } \\
\text { ut } \\
\text { u } \\
\text { ai } \\
\text { r }\end{array}$ & $\begin{array}{l}0 \\
, \\
0 \\
1 \\
8\end{array}$ & $\begin{array}{c}\text { T } \\
\text { id } \\
\text { a } \\
k \\
\text { m } \\
\text { el } \\
\text { e } \\
\text { W } \\
\text { at } \\
\text { i } \\
\text { b } \\
\text { at } \\
\text { a } \\
\text { s } \\
\text { b } \\
\text { a } \\
k \\
\text { u } \\
\text { m } \\
\text { ut } \\
\text { u } \\
\text { ai } \\
\text { r }\end{array}$ & $\begin{array}{l}1 \\
0 \\
4\end{array}$ & $\begin{array}{c}\text { T } \\
\text { id } \\
\mathrm{a} \\
\mathrm{k} \\
\mathrm{m} \\
\mathrm{el} \\
\mathrm{e} \\
\mathrm{W} \\
\mathrm{at} \\
\mathrm{i} \\
\mathrm{b} \\
\mathrm{at} \\
\mathrm{a} \\
\mathrm{s} \\
\mathrm{b} \\
\mathrm{a} \\
\mathrm{k} \\
\mathrm{u} \\
\mathrm{m} \\
\mathrm{ut} \\
\mathrm{u} \\
\mathrm{ai} \\
\mathrm{r}\end{array}$ & $\begin{array}{l}3 \\
6 \\
6 \\
4\end{array}$ & $\begin{array}{c}\text { T } \\
\text { id } \\
\mathrm{a} \\
\mathrm{k} \\
\mathrm{m} \\
\mathrm{el} \\
\mathrm{e} \\
\mathrm{W} \\
\mathrm{at} \\
\mathrm{i} \\
\mathrm{b} \\
\mathrm{at} \\
\mathrm{a} \\
\mathrm{s} \\
\mathrm{b} \\
\mathrm{a} \\
\mathrm{k} \\
\mathrm{u} \\
\mathrm{m} \\
\mathrm{ut} \\
\mathrm{u} \\
\mathrm{ai} \\
\mathrm{r}\end{array}$ \\
\hline
\end{tabular}

\begin{tabular}{|c|c|c|c|c|c|c|c|c|c|c|c|}
\hline & & & & & $\begin{array}{l}\mathrm{m} \\
\text { in } \\
\mathrm{u} \\
\mathrm{m}\end{array}$ & & $\begin{array}{l}\mathrm{m} \\
\text { in } \\
\mathrm{u}\end{array}$ & & $\begin{array}{c}\mathrm{m} \\
\text { in } \\
\mathrm{u} \\
\mathrm{m}\end{array}$ & & $\begin{array}{l}\mathrm{m} \\
\text { in } \\
\mathrm{u} \\
\mathrm{m}\end{array}$ \\
\hline \multirow{27}{*}{$\begin{array}{c}\text { II } \\
\text { I } \\
\text { B }\end{array}$} & \multirow[t]{27}{*}{1} & \multirow{27}{*}{3} & $\mathrm{M}$ & \multirow{2}{*}{$\begin{array}{l}< \\
0\end{array}$} & $\mathrm{~T}$ & 0 & $\mathrm{~T}$ & 0 & $\mathrm{~T}$ & \multirow{2}{*}{$<$} & $\mathrm{T}$ \\
\hline & & & el & & id & , & id & , & $\mathrm{id}$ & & id \\
\hline & & & $\mathrm{e}$ & , & $\mathrm{a}$ & 0 & $\mathrm{a}$ & 0 & $\mathrm{a}$ & , & $\mathrm{a}$ \\
\hline & & & W & 0 & $\mathrm{k}$ & 2 & $\mathrm{k}$ & 6 & $\mathrm{k}$ & 3 & $\mathrm{k}$ \\
\hline & & & at & 1 & $\mathrm{~m}$ & 6 & $\mathrm{~m}$ & 1 & $\mathrm{~m}$ & 9 & $\mathrm{~m}$ \\
\hline & & & $\mathrm{i}$ & & el & & el & & el & & el \\
\hline & & & b & & $\mathrm{e}$ & & $\mathrm{e}$ & & $\mathrm{e}$ & & $\mathrm{e}$ \\
\hline & & & at & & W & & W & & W & & W \\
\hline & & & $\mathrm{a}$ & & at & & at & & at & & at \\
\hline & & & $\mathrm{S}$ & & $\mathrm{i}$ & & $\mathrm{i}$ & & $\mathrm{i}$ & & $\mathrm{i}$ \\
\hline & & & b & & $b$ & & b & & b & & b \\
\hline & & & $\mathrm{a}$ & & at & & at & & at & & at \\
\hline & & & $\mathrm{k}$ & & $\mathrm{a}$ & & $\mathrm{a}$ & & $\mathrm{a}$ & & $\mathrm{a}$ \\
\hline & & & $\mathrm{u}$ & & $\mathrm{S}$ & & $\mathrm{S}$ & & $\mathrm{S}$ & & $\mathrm{S}$ \\
\hline & & & $\mathrm{m}$ & & b & & b & & b & & b \\
\hline & & & ut & & $\mathrm{a}$ & & $\mathrm{a}$ & & $\mathrm{a}$ & & $\mathrm{a}$ \\
\hline & & & $\mathrm{u}$ & & $\mathrm{k}$ & & $\mathrm{k}$ & & $\mathrm{k}$ & & $\mathrm{k}$ \\
\hline & & & ai & & $\mathrm{u}$ & & $\mathrm{u}$ & & $\mathrm{u}$ & & $\mathrm{u}$ \\
\hline & & & $\mathrm{r}$ & & $\mathrm{m}$ & & $\mathrm{m}$ & & $\mathrm{m}$ & & $\mathrm{m}$ \\
\hline & & & $\mathrm{m}$ & & ut & & ut & & ut & & ut \\
\hline & & & in & & $\mathrm{u}$ & & $\mathrm{u}$ & & $\mathrm{u}$ & & $\mathrm{u}$ \\
\hline & & & $\mathrm{u}$ & & ai & & ai & & ai & & ai \\
\hline & & & $\mathrm{m}$ & & $\mathrm{r}$ & & $\mathrm{r}$ & & $\mathrm{r}$ & & $\mathrm{r}$ \\
\hline & & & & & $\mathrm{m}$ & & $\mathrm{m}$ & & $\mathrm{m}$ & & $\mathrm{m}$ \\
\hline & & & & & in & & in & & in & & in \\
\hline & & & & & $\mathrm{u}$ & & $\mathrm{u}$ & & $\mathrm{u}$ & & $\mathrm{u}$ \\
\hline & & & & & $\mathrm{m}$ & & $\mathrm{m}$ & & $\mathrm{m}$ & & $\mathrm{m}$ \\
\hline I & 1 & 8 & $\mathrm{~T}$ & 0 & $\mathrm{M}$ & 0 & $\mathrm{~T}$ & 1 & $\mathrm{~T}$ & $<$ & $\mathrm{T}$ \\
\hline V & 2 & , & id & , & el & , & id & , & id & 0 & id \\
\hline$A$ & 6 & 2 & $\mathrm{a}$ & 3 & $\mathrm{e}$ & 0 & $\mathrm{a}$ & 0 & $\mathrm{a}$ & , & $\mathrm{a}$ \\
\hline & & & $\mathrm{k}$ & 3 & $\mathrm{~W}$ & 3 & $\mathrm{k}$ & 4 & $\mathrm{k}$ & 3 & $\mathrm{k}$ \\
\hline & & & $\mathrm{m}$ & & at & 4 & $\mathrm{~m}$ & & $\mathrm{~m}$ & 9 & $\mathrm{~m}$ \\
\hline & & & el & & $\mathrm{i}$ & & el & & el & & el \\
\hline & & & $\mathrm{e}$ & & b & & $\mathrm{e}$ & & $\mathrm{e}$ & & e \\
\hline & & & W & & at & & W & & W & & W \\
\hline & & & at & & $\mathrm{a}$ & & at & & at & & at \\
\hline & & & $\mathrm{i}$ & & $\mathrm{S}$ & & $\mathrm{i}$ & & $\mathrm{i}$ & & $\mathrm{i}$ \\
\hline & & & b & & b & & $b$ & & b & & b \\
\hline & & & at & & $\mathrm{a}$ & & at & & at & & at \\
\hline & & & $\mathrm{a}$ & & $\mathrm{k}$ & & $\mathrm{a}$ & & $\mathrm{a}$ & & $\mathrm{a}$ \\
\hline & & & $\mathrm{S}$ & & $\mathrm{u}$ & & $\mathrm{S}$ & & $\mathrm{S}$ & & $\mathrm{S}$ \\
\hline & & & b & & $\mathrm{m}$ & & b & & b & & b \\
\hline & & & $\mathrm{a}$ & & ut & & $\mathrm{a}$ & & $\mathrm{a}$ & & $\mathrm{a}$ \\
\hline & & & $\mathrm{k}$ & & $\mathrm{u}$ & & $\mathrm{k}$ & & $\mathrm{k}$ & & $\mathrm{k}$ \\
\hline & & & $\mathrm{u}$ & & $\mathrm{ai}$ & & $\mathrm{u}$ & & $\mathrm{u}$ & & $\mathrm{u}$ \\
\hline & & & $\mathrm{m}$ & & $\mathrm{r}$ & & $\mathrm{m}$ & & $\mathrm{m}$ & & $\mathrm{m}$ \\
\hline & & & ut & & $\mathrm{m}$ & & ut & & ut & & ut \\
\hline & & & $\mathrm{u}$ & & in & & $\mathrm{u}$ & & $\mathrm{u}$ & & $\mathrm{u}$ \\
\hline & & & $\mathrm{ai}$ & & $\mathrm{u}$ & & ai & & ai & & ai \\
\hline & & & $r$ & & $\mathrm{~m}$ & & $\mathrm{r}$ & & $\mathrm{r}$ & & $\mathrm{r}$ \\
\hline & & & $\mathrm{m}$ & & & & $\mathrm{m}$ & & $\mathrm{m}$ & & $\mathrm{m}$ \\
\hline & & & in & & & & in & & in & & in \\
\hline
\end{tabular}




\begin{tabular}{|c|c|c|c|c|c|c|c|c|c|c|c|}
\hline & & & $\begin{array}{c}\mathrm{u} \\
\mathrm{m}\end{array}$ & & & & $\begin{array}{c}\mathrm{u} \\
\mathrm{m}\end{array}$ & & $\begin{array}{l}\mathrm{u} \\
\mathrm{m}\end{array}$ & & $\begin{array}{l}\mathrm{u} \\
\mathrm{m}\end{array}$ \\
\hline I & 1 & 9 & $\bar{M}$ & $<$ & $\mathrm{T}$ & 0 & $\mathrm{~T}$ & 1 & $\mathrm{~T}$ & $<$ & $\mathrm{T}$ \\
\hline V & 2 & 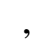 & el & 0 & id & . & id & . & id & 0 & id \\
\hline B & 6 & 4 & $\mathrm{e}$ & & $\mathrm{a}$ & 0 & $\mathrm{a}$ & 0 & $\mathrm{a}$ & & $\mathrm{a}$ \\
\hline & & & $\mathrm{w}$ & 0 & $\mathrm{k}$ & 0 & $\mathrm{k}$ & 2 & $\mathrm{k}$ & 3 & $\mathrm{k}$ \\
\hline & & & at & 1 & $\mathrm{~m}$ & 9 & $\mathrm{~m}$ & & $\mathrm{~m}$ & 9 & $\mathrm{~m}$ \\
\hline & & & $\mathrm{i}$ & & el & & el & & el & & el \\
\hline & & & b & & $\mathrm{e}$ & & $\mathrm{e}$ & & $\mathrm{e}$ & & $\mathrm{e}$ \\
\hline & & & at & & W & & W & & W & & W \\
\hline & & & $\mathrm{a}$ & & at & & at & & at & & at \\
\hline & & & $\mathrm{S}$ & & $\mathrm{i}$ & & $\mathrm{i}$ & & $\mathrm{i}$ & & $\mathrm{i}$ \\
\hline & & & b & & b & & $b$ & & $b$ & & b \\
\hline & & & $\mathrm{a}$ & & at & & at & & at & & at \\
\hline & & & $\mathrm{k}$ & & $\mathrm{a}$ & & $\mathrm{a}$ & & $\mathrm{a}$ & & $\mathrm{a}$ \\
\hline & & & $\mathrm{u}$ & & $\mathrm{s}$ & & $\mathrm{S}$ & & $\mathrm{S}$ & & $\mathrm{S}$ \\
\hline & & & $\mathrm{m}$ & & $b$ & & $b$ & & $b$ & & b \\
\hline & & & ut & & $\mathrm{a}$ & & $\mathrm{a}$ & & $\mathrm{a}$ & & $\mathrm{a}$ \\
\hline & & & $\mathrm{u}$ & & $\mathrm{k}$ & & $\mathrm{k}$ & & $\mathrm{k}$ & & $\mathrm{k}$ \\
\hline & & & $\mathrm{ai}$ & & $\mathrm{u}$ & & $\mathrm{u}$ & & $\mathrm{u}$ & & $\mathrm{u}$ \\
\hline & & & $\mathrm{r}$ & & $\mathrm{m}$ & & $\mathrm{m}$ & & $\mathrm{m}$ & & $\mathrm{m}$ \\
\hline & & & $\mathrm{m}$ & & ut & & ut & & ut & & ut \\
\hline & & & in & & $\mathrm{u}$ & & $\mathrm{u}$ & & $\mathrm{u}$ & & $\mathrm{u}$ \\
\hline & & & $\mathrm{u}$ & & ai & & ai & & ai & & ai \\
\hline & & & $\mathrm{m}$ & & $\mathrm{r}$ & & $\mathrm{r}$ & & $\mathrm{r}$ & & $\mathrm{r}$ \\
\hline & & & & & $\mathrm{m}$ & & $\mathrm{m}$ & & $\mathrm{m}$ & & $\mathrm{m}$ \\
\hline & & & & & in & & in & & in & & in \\
\hline & & & & & $\mathrm{u}$ & & $\mathrm{u}$ & & $\mathrm{u}$ & & $\mathrm{u}$ \\
\hline & & & & & $\mathrm{m}$ & & $\mathrm{m}$ & & $\mathrm{m}$ & & $\mathrm{m}$ \\
\hline V & 1 & 8 & $\mathrm{M}$ & 0 & $\mathrm{~T}$ & 0 & $\mathrm{~T}$ & 1 & $\mathrm{~T}$ & $<$ & $\mathrm{T}$ \\
\hline I & 3 & , & el & . & id & 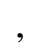 & id & 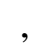 & id & 0 & id \\
\hline A & 2 & 9 & $\mathrm{e}$ & 0 & $\mathrm{a}$ & 0 & $\mathrm{a}$ & 0 & $\mathrm{a}$ & & $\mathrm{a}$ \\
\hline & & & W & 1 & $\mathrm{k}$ & 0 & $\mathrm{k}$ & 6 & $\mathrm{k}$ & 3 & $\mathrm{k}$ \\
\hline & & & at & 7 & $\mathrm{~m}$ & 4 & $\mathrm{~m}$ & & $\mathrm{~m}$ & 9 & $\mathrm{~m}$ \\
\hline & & & $\mathrm{i}$ & & el & 2 & el & & el & & el \\
\hline & & & $b$ & & $\mathrm{e}$ & & $\mathrm{e}$ & & $\mathrm{e}$ & & $\mathrm{e}$ \\
\hline & & & at & & $\mathrm{w}$ & & W & & W & & w \\
\hline & & & $\mathrm{a}$ & & at & & at & & at & & at \\
\hline & & & $\mathrm{s}$ & & $\mathrm{i}$ & & $\mathrm{i}$ & & $\mathrm{i}$ & & $\mathrm{i}$ \\
\hline & & & $b$ & & $b$ & & b & & b & & $b$ \\
\hline & & & $\mathrm{a}$ & & at & & at & & at & & at \\
\hline & & & $\mathrm{k}$ & & $\mathrm{a}$ & & $\mathrm{a}$ & & $\mathrm{a}$ & & $\mathrm{a}$ \\
\hline & & & $\mathrm{u}$ & & $\mathrm{S}$ & & $\mathrm{S}$ & & $S$ & & $\mathrm{~s}$ \\
\hline & & & $\mathrm{m}$ & & $b$ & & $b$ & & $b$ & & $b$ \\
\hline & & & ut & & $\mathrm{a}$ & & $\mathrm{a}$ & & $\mathrm{a}$ & & $\mathrm{a}$ \\
\hline & & & $\mathrm{u}$ & & $\mathrm{k}$ & & $\mathrm{k}$ & & $\mathrm{k}$ & & $\mathrm{k}$ \\
\hline & & & ai & & $\mathrm{u}$ & & $\mathrm{u}$ & & $\mathrm{u}$ & & $\mathrm{u}$ \\
\hline & & & $\mathrm{r}$ & & $\mathrm{m}$ & & $\mathrm{m}$ & & $\mathrm{m}$ & & $\mathrm{m}$ \\
\hline & & & $\mathrm{m}$ & & ut & & ut & & ut & & ut \\
\hline & & & in & & $\mathrm{u}$ & & $\mathrm{u}$ & & $\mathrm{u}$ & & $\mathrm{u}$ \\
\hline & & & $\mathrm{u}$ & & ai & & ai & & ai & & ai \\
\hline & & & $\mathrm{m}$ & & $\mathrm{r}$ & & $\mathrm{r}$ & & $\mathrm{r}$ & & $\mathrm{r}$ \\
\hline & & & & & $\mathrm{m}$ & & $\mathrm{m}$ & & $\mathrm{m}$ & & $\mathrm{m}$ \\
\hline & & & & & in & & in & & in & & in \\
\hline & & & & & $\mathrm{u}$ & & $\mathrm{u}$ & & $\mathrm{u}$ & & $\mathrm{u}$ \\
\hline & & & & & $\mathrm{m}$ & & $\mathrm{m}$ & & $\mathrm{m}$ & & $\mathrm{m}$ \\
\hline
\end{tabular}

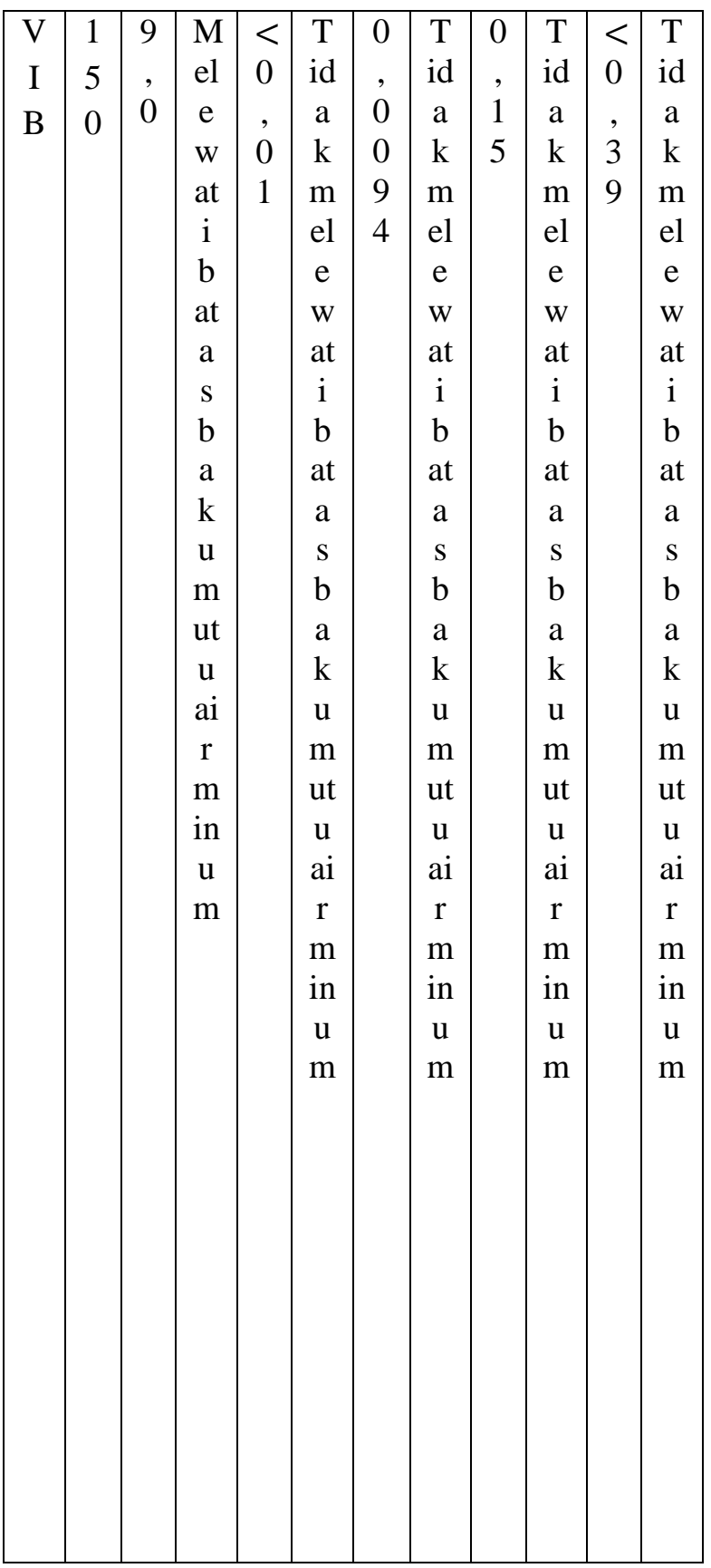

*melalui informasi masyarakat Desa Pekan Bandar Khalifah

3.2 PEMBAHASAN

Analisis Indeks Pencemaran Air Sumur Bor

Tabel 3.3. Status mutu air untuk peruntukan air minum

\begin{tabular}{|l|l|l|l|l|}
\hline $\begin{array}{l}\text { No } \\
\cdot\end{array}$ & $\begin{array}{l}\text { Sampe } \\
\text { I Air } \\
\text { Sumur }\end{array}$ & $\begin{array}{l}\text { Lokas } \\
\text { i }\end{array}$ & $\begin{array}{l}\text { IP } \\
\text { BMA } \\
\text { Minu } \\
\text { m }\end{array}$ & $\begin{array}{l}\text { Status } \\
\text { Mutu } \\
\text { Air }\end{array}$ \\
\hline 1. & IA & $\begin{array}{l}\text { Dusun } \\
\text { I }\end{array}$ & 1,46 & $\begin{array}{l}\text { Cemar } \\
\text { Ringa } \\
\mathrm{n}\end{array}$ \\
\hline
\end{tabular}




\begin{tabular}{|c|c|c|c|c|}
\hline 2. & IB & $\begin{array}{l}\text { Dusun } \\
\text { I }\end{array}$ & 1,46 & $\begin{array}{l}\text { Cemar } \\
\text { Ringa } \\
\mathrm{n}\end{array}$ \\
\hline 3. & IIA & $\begin{array}{l}\text { Dusun } \\
\text { II }\end{array}$ & 1,12 & $\begin{array}{l}\text { Cemar } \\
\text { Ringa } \\
\mathrm{n}\end{array}$ \\
\hline 4. & IIB & $\begin{array}{l}\text { Dusun } \\
\text { II }\end{array}$ & 1,30 & $\begin{array}{l}\text { Cemar } \\
\text { Ringa } \\
\mathrm{n}\end{array}$ \\
\hline 5. & IIIA & $\begin{array}{l}\text { Dusun } \\
\text { III }\end{array}$ & 1,23 & $\begin{array}{l}\text { Cemar } \\
\text { Ringa } \\
\mathrm{n}\end{array}$ \\
\hline 6. & IIIB & $\begin{array}{l}\text { Dusun } \\
\text { III }\end{array}$ & 1,30 & $\begin{array}{l}\text { Cemar } \\
\text { Ringa } \\
\mathrm{n}\end{array}$ \\
\hline 7. & IVA & $\begin{array}{l}\text { Dusun } \\
\text { IV }\end{array}$ & 2,21 & $\begin{array}{l}\text { Cemar } \\
\text { Ringa } \\
\mathrm{n}\end{array}$ \\
\hline 8. & IVB & $\begin{array}{l}\text { Dusun } \\
\text { IV }\end{array}$ & 1,38 & $\begin{array}{l}\text { Cemar } \\
\text { Ringa } \\
\mathrm{n}\end{array}$ \\
\hline 9. & VIA & $\begin{array}{l}\text { Dusun } \\
\text { VI }\end{array}$ & 1,03 & $\begin{array}{l}\text { Cemar } \\
\text { Ringa } \\
\mathrm{n}\end{array}$ \\
\hline 10. & VIB & $\begin{array}{l}\text { Dusun } \\
\text { VI }\end{array}$ & 1,09 & $\begin{array}{l}\text { Cemar } \\
\text { Ringa } \\
\mathrm{n}\end{array}$ \\
\hline
\end{tabular}

Keterangan :

IP $=$ Indeks Pencemaran

BMA = Baku Mutu Air

Berdasarkan hasil perhitungan di atas, diperoleh mutu kualitas air rata-rata terhadap semua sampel tiap-tiap lokasi yaitu tergolong Cemar Ringan.

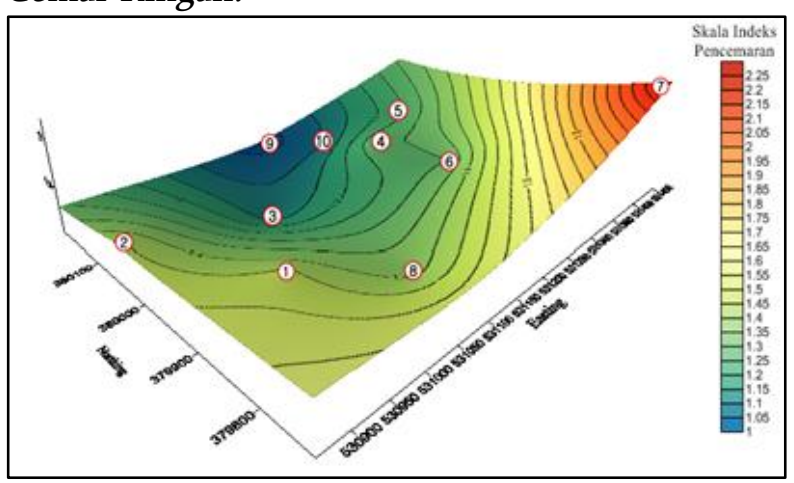

Gambar 3.1. Peta kontur indeks pencemaran air sumur bor Desa Pekan
Dari peta kontur pada gambar 3.1. dapat terlihat bahwa indeks pencemaran tertinggi terdapat pada titik 7 yakni sampel IVA sebesar 2,21 . Diprediksikan tingginya pencemaran di daerah tersebut adanya industri yang menyebabkan tanah tersebut menyerap limbah, baik limbah padat maupun limbah cair, karena tempat disekitarnya yakni titik 1, 2, 3, 4, 5, 6, 8, 9, dan 10 jauh dari titik 7.

Analisis Hubungan Zat Padat Terlarut (TDS) terhadap Kekeruhan

Dari gambar 3.2. terlihat semakin tinggi nilai kekeruhan yang terdapat di dalam air sumur bor maka semakin tinggi juga nilai zat padat terlarut didalamnya, dan sebaliknya semakin rendah nilai kekeruhan yang terdapat di dalam air maka semakin rendah juga nilai zat padat terlarut didalamnya (Mulyani,2012). Berdasarkan nilai koefisien determinasi dari grafik diperoleh hubungan yang signifikan antara zat padat terlarut terhadap kekeruhan, dengan nilai 0,995 atau sekitar 99,5 \% kekeruhan air sumur mempengaruhi zat padat terlarut dalam air.

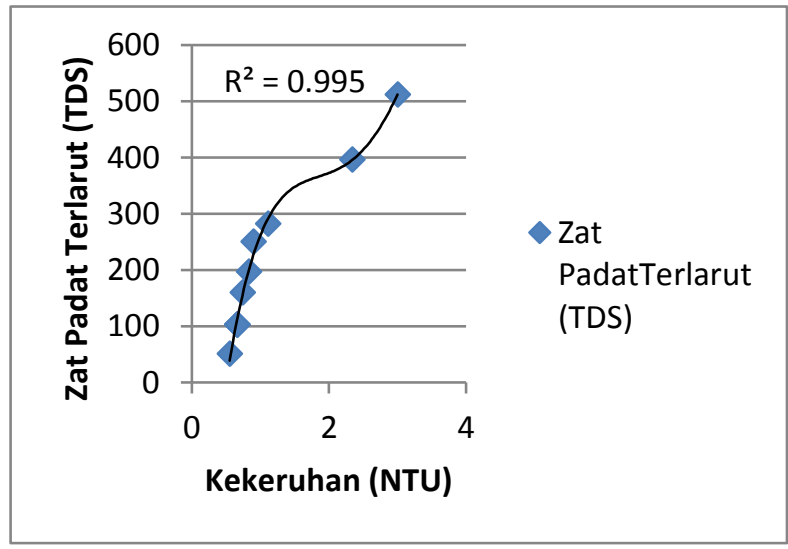

Gambar 3.2. Grafik hubungan zat padat terlarut terhadap kekeruhan

Nilai zat padat terlarut tertinggi terdapat pada sampel IVA sebesar $512 \mathrm{mg} / \mathrm{l}$ dengan kekeruhan tertinggi sebesar 3,00 NTU. Tingginya nilai kekeruhan di daerah tersebut dipengaruhi oleh limbah rumah tangga dan limbah persawahan yang membuat air tersebut mengandung begitu banyak partikel bahan yang tersuspensi dan terlarut. Nilai zat padat terlarut terendah terdapat pada sampel IIB sebesar 51 $\mathrm{mg} / \mathrm{l}$ dengan nilai kekeruhan terendah sebesar 0,55 NTU. 


\section{KESIMPULAN DAN SARAN}

Dari hasil penelitian yang dilakukan dapat dibuat kesimpulan, antara lain :

1. Kualitas air sumur bor di Desa Pekan Bandar Khalifah Kabupaten Serdang Bedagai berdasarkan kualitas fisika terdapat nilai kekeruhan maksimum 3,00 NTU dan minimum 0,55 NTU; nilai zat padat terlarut maksimum $512 \mathrm{mg} / \mathrm{l}$ dan minimum $51 \mathrm{mg} / \mathrm{l}$; dengan kategori cemar ringan. Berdasarkan kualitas kimia terdapat nilai $\mathrm{pH}$ rata-rata 9,16; kandungan besi maksimum $0,33 \mathrm{mg} / \mathrm{l}$ dan minimum $\quad 0,0036 \mathrm{mg} / \mathrm{l} ; \quad$ kandungan mangan maksimum 0,034 mg/l dan minimum $0,0042 \mathrm{mg} / \mathrm{l}$; kandungan nitrit maksimum $1,11 \mathrm{mg} / \mathrm{l}$ dan minimum $0,014 \mathrm{mg} / \mathrm{l}$; kandungan sulfat $5,44 \mathrm{mg} / \mathrm{l}$ dan minimum $<0,39 \mathrm{mg} / \mathrm{l}$; dengan kategori cemar ringan.

2. Dari hasil analisa terlihat bahwa air sumur bor di Desa Pekan Bandar Khalifah mengalami cemar ringan untuk kualitas air minum, dengan nilai cemar maksimum 2,21 pada sampel IVA dan nilai cemar minimum 1,03 pada sampel VIA. Dengan demikian air sumur bor tersebut dapat dikonsumsi setelah diolah terlebih dahulu.

\section{SARAN}

Dari hasil penelitian yang dilakukan maka disarankan :

1. Adanya studi yang dilakukan dengan menggunakan metode lain sehingga didapatkan hasil yang saling melengkapi antara satu dengan lainnya.

2. Diharapkan adanya perhatian pemerintah untuk mengadakan solusi untuk mencari sumber air yang lain agar masyarakat tidak bergantung kepada air tanah dangkal (air sumur) misalnya dengan memperluas pengadaan aliran air dari PDAM.

3. Kepada masyarakat setempat agar membuat sistem pengolahan air sehingga air tanah dapat dikonsumsi, dengan cara :

a) Aerasi, maksudnya dengan mengalirkan oksigen ke dalam air. Di lapangan prakteknya adalah dengan mengalirkan air seperti pancuran, tetapi dibuat bertingkat sehingga percikan air itulah yang mengikat oksigen di udara.

b) Adsorbsi, menggunakan karbon aktif. Air disaring dengan karbon aktif (arang yang di produksi di pabrik atau batok kelapa). Hancurkan sampai berbentuk butiran halus, bilas dengan air sebelum dipakai. Pembilasan awal ini untuk membuang debu atau material halus. $1 \mathrm{~kg}$ arang aktif hanya bisa untuk 100L air.

c) Filtrasi, pembersihan partikel padat dari suatu fluida dengan melewatkan medium penyaringan.

\section{DAFTAR PUSTAKA}

Kementerian Negara Lingkungan Hidup, (2003), Keputusan Menteri Lingkungan

Hidup No.115 Tentang Pedoman Penentuan Status Mutu Air Dengan

Metode Indeks Pencemaran, Deputi MENLH, Jakarta

Menteri Kesehatan Republik Indonesia, (2010), Peraturan Menteri Kesehatan

No.492 Mengenai Persyaratan Kualitas Air Minum, Jakarta

Mulyani., (2012), Analisis Spasial Kualitas Air Sungai Berdasarkan Parameter

Fisik di Sepanjang Krueng Daroy Banda Aceh., Skripsi, Universitas

Syiahkuala, Banda Aceh

Parera, M.J., Supit, W., dan Rumampuk, J.F., (2013), Analisis Perbedaan Pada Uji

Kualitas Air Sumur di Kelurahan Madidir Ure Kota Bitung Berdasarkan

Parameter Fisika, Jurnal e-Biomedik (eBM) Vol.1 No.1: 466-472

Rolia, Eva., (2011), Penggunaan Metode Geolistrik Untuk Mendeteksi

Keberadaan Air Tanah, Jurnal TAPAK Vol.1 No.1

Suryana, Rifda., (2013), Analisis Kualitas Air Sumur Dangkal di Kecamatan 
Donita Manurung dan Eva Marlina Ginting, Analisis Air Sumur Bor Desa Pekan Bandar Khalifah Kabupaten Serdang Bedagai Berdasarkan Kualitas Fisika Dan Kimia

Biringkanayya Kota Makassar., Skripsi, Universitas Hasanuddin, Makassar 